\title{
Inbreeding effects on body weight traits of Iranian Moghani sheep
}

\author{
Navid Ghavi Hossein-Zadeh \\ Department of Animal Science, Faculty of Agriculture, University of Guilan, Rasht, Iran
}

\begin{abstract}
The objective of the present study was to evaluate the effects of inbreeding on body weight at different ages in Moghani sheep. Traits included were birth weight (BW), 3-month weight (3MW), 6-month weight (6MW), 9-month weight (9MW), and yearling weight (YW). Data and pedigree information used in this study were collected at the Breeding Station of Moghani sheep, Iran during 1987-2005. All the animals were grouped into three classes according to the inbreeding coefficients obtained by their pedigree: the first class included non-inbred animals ( $\mathrm{F}=0 \%)$; and the second and third classes included inbred animals $(0<\mathrm{F} \leq 0.10$ and $\mathrm{F}>0.10$, respectively). Average inbreeding rate was $2.93 \%$ in the pedigree of Moghani sheep. The BW of animals within second class of inbreeding was significantly higher than those of lambs belonging to the third class $(P<0.05)$. The $3 \mathrm{MW}$ of animals within third class of inbreeding was significantly $(P<0.05)$ higher than those of lambs belonging to the first and second classes. The $6 \mathrm{MW}$ of animals within third class of inbreeding was significantly $(P<0.05)$ lower than those of lambs belonging to the first and second classes. Animals within third class of inbreeding had greater mean of $9 \mathrm{MW}$ than two other groups $(P<0.05)$. Also, the YW of animals within second class of inbreeding was significantly $(P<0.05)$ lower than those of lambs belonging to the first and third classes. The utilization of designed mating system could be a suitable approach to maintain the level of inbreeding under control.
\end{abstract}

Keywords: fat-tailed sheep, growth trait, inbreeding depression

\section{Introduction}

One definition for inbreeding is given by the mating of individuals whose relatedness between them is greater than the average degree of relationship existing in the population (Lush 1945), and capable of changing the genotypic frequencies of a population without modifying the gene frequencies. Most inbreeding results from the intensive use of a few breeding animals, where the selection intensity is high. Thus, a small number of seedstock, with a strong family relationship, is responsible for the maintenance of almost the whole genetic pool in the population. This is an aspect of great influence in the genealogical analysis of a population structure, because of its effect on the probability of genes lost between generations and the consequent reduction in genetic variability (Pedrosa et al. 2010).

Heterozygosity and allelic diversities can be lost from small, closed, selected populations at a rapid rate. The loss of diversity and resulting increase in homozygosity may result in decreased productions and/or fitness of inbred animals. Furthermore, inbreeding depression 
in domestic animals can lead to a decrease in selection response and in potential genetic gains in economic traits. Measurement of the effect of inbreeding on these traits is important in order to estimate the magnitude of change associated with increases in inbreeding. The inbreeding depression has been well documented in many populations for a variety of traits (Lamberson \& Thomas 1984, Ercanbrack \& Knight 1991, Analla et al. 1998, Dario \& Bufano 2003, Khan et al. 2007, Van Wyk et al. 2009). Inbreeding impairs growth, productions, health, reproduction traits (such as fertility) and survival. The emergence of disorders due to recessive gene action may also occur. It is apparent that different breeds and populations, as well as different traits vary in their response to inbreeding. Some populations may show a very pronounced effect of increased inbreeding for a trait, whereas others may not demonstrate much of an effect (Negussie et al. 2002, Barczak et al. 2009).

The rate of inbreeding needs to be limited to maintain diversity at an acceptable level so that genetic variation will ensure that future animals can respond to changes in the environment and to selection. Without genetic variation, animals cannot adapt to these changes (Van Wyk et al. 2009). The objective of this study was to evaluate the effects of inbreeding on different weights of Iranian Moghani sheep over a 19-year period from 1987 to 2005 .

\section{Material and methods}

\section{Data and pedigree information}

Moghani breed, numbering about 5.5 million, is one of the most important meat breeds among Iranian sheep. They are well-known for their large size, tolerance to climatic changes and capability to produce heavy lambs (Shodja 2006). The breed is fat-tailed, its coat colour is predominantly white and its face, legs and feets are brown. In this breed, both sexes are polled. A breeding station of Moghani breed was established in 1952 in Ardebil province of Iran in order to genetically improve the performance of Moghani sheep, through identifying the best rams and distributing them to the commercial flocks. Body weights at birth, weaning and at higher ages were sometimes considered as criteria in selection of replacements. Data and pedigree information used in this study were collected at the breeding station of Moghani sheep from 1987 to 2005. The included traits were: birth weight (BW), 3-month weight (3MW), 6-month weight (6MW), 9-month weight (9MW), and yearling weight (YW). The CFC program (Sargolzaei et al. 2006) was used to calculate pedigree statistics and regular inbreeding coefficients for individuals in the pedigree. The number of animals (in total), inbred animals, sires, dams, founders and non founders in the pedigree of Moghani sheep were $8494,1060,625,2828,1835$ and 6659, respectively. Also, there were totally 1210 full-sib groups with average family size of 2.12 in the pedigree of Moghani sheep. On the basis of individual inbreeding coefficient, all the animals were grouped in three classes: first class including non-inbred animals $(F=0)$; second and third classes including inbred animals $(0<\mathrm{F} \leq 0.10$ and $\mathrm{F}>0.10$, respectively). The incidences of triplets and quadruplets were so low $(<0.8 \%)$ that records from lambs born in triplet and quadruplet litters were discarded. 


\section{Statistical analysis}

The effects of inbreeding rate on body weight traits were analysed using the linear mixed model (Proc Mixed) with the best fitted covariance structure of SAS 9.1 (SAS Institute Inc., Cary, NC, USA). The least-squares means were estimated by restricted maximum likelihood (REML) method. Level of significance for the inclusion of effects into the model of analysis was declared at $P<0.05$. The final model included the fixed class effects of year-season ( 76 levels), inbreeding class, sex of lamb, parity of dam, litter size (single and twin), age of dam (from 2 through 7 years old) and random effect of animal. All the interactions of first order were included in the preliminary models, but only sex by parity, litter size by inbreeding class, sex by inbreeding class and litter size by parity interaction effects were kept in the final models. Trend of inbreeding was estimated using the linear regression of individual inbreeding on birth year. Also, inbreeding depression was estimated as the regression of body weight traits on the individual inbreeding coefficients.

\section{Results}

The analysis of pedigree revealed that inbreeding rate ranged from 0 to $28.13 \%$ with an average of $2.93 \%$. Figure 1 shows the average of inbreeding coefficients over years. The trend of inbreeding was significantly positive over the years $(P<0.05)$ and its estimate was $0.027 \pm 0.011$. Table 1 shows the summary statistics for body weight traits in different inbreeding classes of animals. The BW of animals within second class of inbreeding was higher than those of lambs belonging to the first and third classes, but only differences were

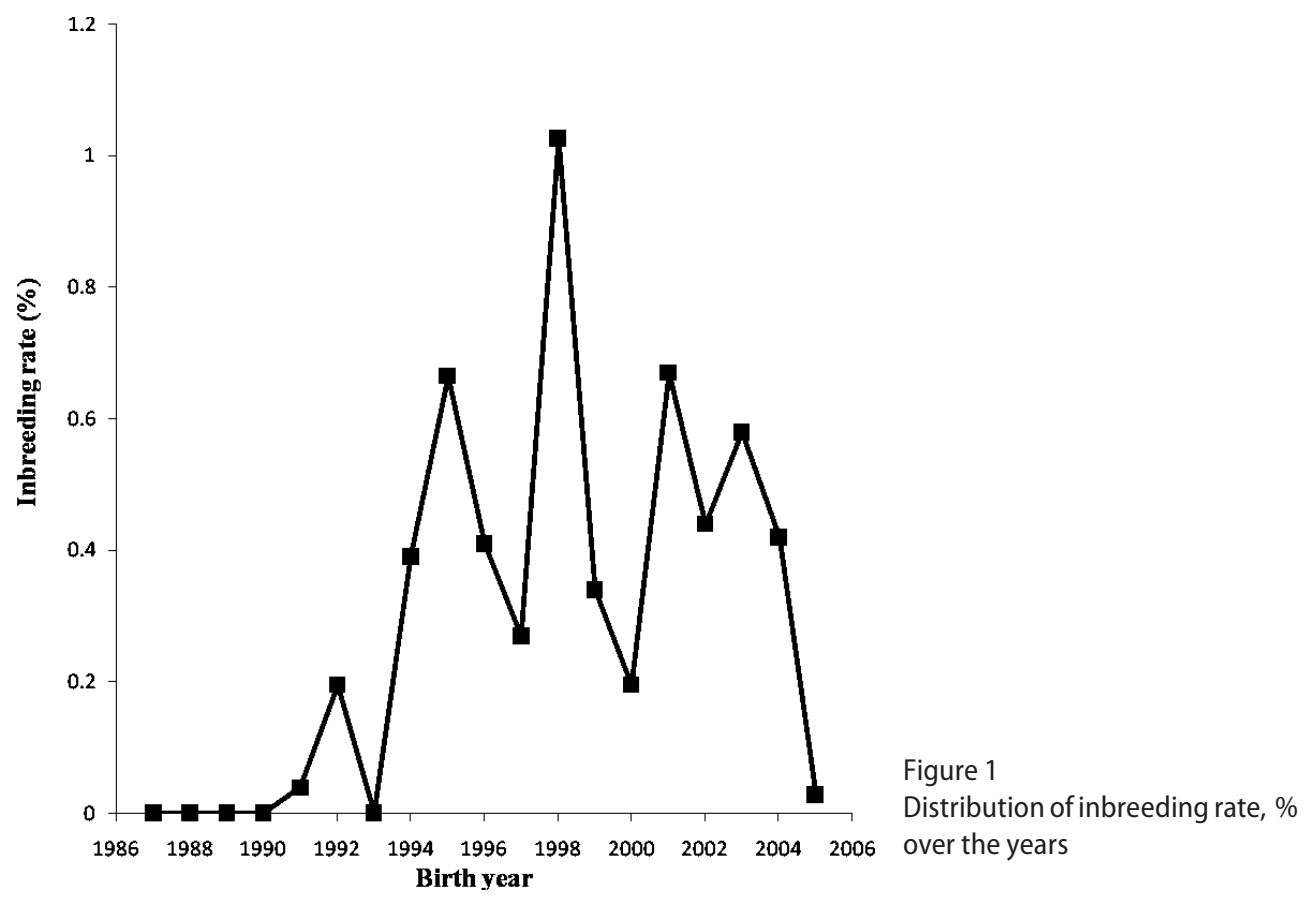


significant only between second and third classes $(P<0.05)$. The $3 \mathrm{MW}$ of animals within third class of inbreeding was significantly $(P<0.05)$ higher than those of lambs belonging to the first and second classes but there was no significant differences between the first and second classes of inbreeding. On the other hand, the $6 \mathrm{MW}$ of animals within third class of inbreeding was significantly $(P<0.05)$ lower than those of lambs belonging to the first and second classes. There were significant differences between three classes of inbreeding on $9 \mathrm{MW}$ and animals within third class of inbreeding had greater mean of the trait than two other groups $(P<0.05)$. Also, the YW of animals within second class of inbreeding was significantly $(P<0.05)$ lower than those of lambs belonging to the first and third classes.

Table 1

Distribution of records for body weight traits in different inbreeding classes of animals born between 1987 and 2005

\begin{tabular}{|c|c|c|c|c|c|c|c|c|c|c|}
\hline \multirow[t]{2}{*}{$\begin{array}{l}\text { Inbreeding } \\
\text { class }\end{array}$} & \multicolumn{2}{|c|}{ BW, kg } & \multicolumn{2}{|c|}{$3 \mathrm{MW}, \mathrm{kg}$} & \multicolumn{2}{|c|}{$\begin{array}{c}\text { Trait } \\
6 \mathrm{MW}, \mathrm{kg}\end{array}$} & \multicolumn{2}{|c|}{$9 \mathrm{MW}, \mathrm{kg}$} & \multicolumn{2}{|c|}{$\mathrm{YW}, \mathrm{kg}$} \\
\hline & $\mathrm{N}$ & Mean \pm SD & $\mathrm{N}$ & Mean \pm SD & $\mathrm{N}$ & Mean \pm SD & $\mathrm{N}$ & Mean \pm SD & $\mathrm{N}$ & Mean \pm SD \\
\hline $\mathrm{F}=0$ & 5564 & $4.56 \pm 0.08^{\mathrm{ab}}$ & 3240 & $23.13 \pm 0.55^{\mathrm{a}}$ & 2485 & $34.44 \pm 1.01^{\mathrm{a}}$ & 1843 & $38.45 \pm 0.46^{\mathrm{b}}$ & 1076 & $39.82 \pm 0.46^{\mathrm{a}}$ \\
\hline $0<\mathrm{F} \leq 0.10$ & 945 & $4.62 \pm 0.08^{b}$ & 860 & $23.98 \pm 0.57^{a}$ & 573 & $34.89 \pm 1.04^{\mathrm{a}}$ & 345 & $36.85 \pm 0.50^{\mathrm{a}}$ & 235 & $37.66 \pm 0.46^{b}$ \\
\hline$F>0.10$ & 94 & $4.48 \pm 0.11^{\mathrm{a}}$ & 61 & $24.77 \pm 0.74^{b}$ & 50 & $32.85 \pm 1.24^{b}$ & 40 & $39.80 \pm 0.82^{c}$ & 20 & $40.99 \pm 0.46^{a}$ \\
\hline
\end{tabular}

$\mathrm{a}, \mathrm{b}, \mathrm{c}$ Means within a column that do not have a common superscript are significantly different $(P<0.05)$. BW: birth weight, 3MW: 3-month weight, 6MW: 6-month weight, 9MW:9-month weight, YW: yearling weight

Table 2

Distribution of records for body weight traits in different inbreeding classes of animals grouped by the type of birth and born between 1987 and 2005

\begin{tabular}{|c|c|c|c|c|c|c|c|c|c|c|c|}
\hline \multirow[t]{2}{*}{$\begin{array}{l}\text { Birth } \\
\text { type }\end{array}$} & \multirow[t]{2}{*}{$\begin{array}{l}\text { Inbreeding } \\
\text { class }\end{array}$} & \multicolumn{10}{|c|}{$\begin{array}{r}\text { Trait } \\
6 \mathrm{MW}, \mathrm{kg}\end{array}$} \\
\hline & & $\mathrm{N}$ & Mean \pm SD & $\mathrm{N}$ & Mean \pm SD & $\mathrm{N}$ & Mean \pm SD & $\mathrm{N}$ & Mean \pm SD & $\mathrm{N}$ & Mean $\pm S D$ \\
\hline & $\mathrm{F}=0$ & 1870 & $4.85 \pm 0.69^{\mathrm{a}}$ & 1898 & $24.71 \pm 4.66^{a}$ & 1485 & $36.00 \pm 6.22^{\mathrm{ab}}$ & 1242 & $39.01 \pm 6.05^{\mathrm{ab}}$ & 720 & $40.45 \pm 7.22^{\mathrm{a}}$ \\
\hline \multirow[t]{3}{*}{ Single } & $0<\mathrm{F} \leq 0.10$ & 498 & $4.97 \pm 0.65^{\mathrm{a}}$ & 485 & $25.70 \pm 5.25^{\mathrm{a}}$ & 329 & $34.44 \pm 5.95^{b}$ & 215 & $37.85 \pm 5.51^{b}$ & 153 & $38.15 \pm 5.62^{\mathrm{a}}$ \\
\hline & $F>0.10$ & 36 & $4.85 \pm 0.80^{\mathrm{a}}$ & 36 & $25.13 \pm 5.83^{a}$ & 30 & $37.70 \pm 7.03^{a}$ & 29 & $40.56 \pm 5.67^{a}$ & 17 & $40.72 \pm 6.92^{a}$ \\
\hline & $\mathrm{F}=0$ & 1299 & $4.15 \pm 0.63^{\mathrm{a}}$ & 1342 & $21.11 \pm 4.74^{b}$ & 1000 & $32.50 \pm 5.89^{a}$ & 601 & $37.28 \pm 5.67^{a}$ & 356 & $38.07 \pm 6.92^{\mathrm{a}}$ \\
\hline \multirow[t]{2}{*}{ Twin } & $0<F \leq 0.10$ & 387 & $4.15 \pm 0.61^{\mathrm{a}}$ & 375 & $21.75 \pm 4.60^{b}$ & 244 & $30.69 \pm 5.29^{a}$ & 130 & $35.20 \pm 5.36^{\mathrm{a}}$ & 82 & $36.76 \pm 5.48^{\mathrm{a}}$ \\
\hline & $F>0.10$ & 30 & $4.02 \pm 0.85^{\mathrm{a}}$ & 25 & $24.32 \pm 4.07^{a}$ & 20 & $31.22 \pm 4.49^{a}$ & 11 & $37.93 \pm 7.15^{a}$ & 3 & $42.46 \pm 8.51^{\mathrm{a}}$ \\
\hline
\end{tabular}

a,b Means within a column and for each birth type that do not have a common superscript are significantly different $(P<0.05)$. BW: birth weight, 3MW: 3-month weight, 6MW: 6-month weight, 9MW: 9-month weight, YW: yearling weight

Single- or twin-born lambs showed no significant differences in their BW and YW irrespective of the inbreeding rate (Table 2). In addition, single-born lambs showed no significant differences in their 3MW. But twin-born lambs in the third class of inbreeding had greater $3 \mathrm{MW}$ than those of twin-born lambs belonging to the first and second classes $(P<0.05)$. Although twin-born lambs showed no significant differences in their $6 \mathrm{MW}$ and $9 \mathrm{MW}$, singleborn lambs in the third class of inbreeding showed significant differences on 6MW and 9MW with lambs belonging to the second class (Table 2).

Male lambs showed no significant differences in their BW, 9MW and YW irrespective of the inbreeding rate (Table 3). The $3 \mathrm{MW}$ and $6 \mathrm{MW}$ of male lambs within third class of inbreeding was significantly higher than those of male lambs belonging to the first and second classes 
$(P<0.05)$. Female lambs showed no significant differences in their $3 \mathrm{MW}$ irrespective of the inbreeding rate. The BW and $9 \mathrm{MW}$ of female lambs in third class of inbreeding were significantly different with those of two other groups $(P<0.05)$. The $6 \mathrm{MW}$ of female lambs within first class of inbreeding was significantly $(P<0.05)$ greater than that of female lambs belonging to the second class. On the other hand, the YW of female lambs within third class of inbreeding was significantly $(P<0.05)$ greater than that of female lambs belonging to the second class.

Table 3

Distribution of records for body weight traits in different inbreeding classes of animals grouped by the sex of lamb and born between 1987 and 2005

\begin{tabular}{|c|c|c|c|c|c|c|c|c|c|c|c|}
\hline \multirow[t]{2}{*}{$\begin{array}{l}\text { Lamb } \\
\text { sex }\end{array}$} & \multirow[t]{2}{*}{$\begin{array}{l}\text { Inbreeding } \\
\text { class }\end{array}$} & \multicolumn{10}{|c|}{$\begin{array}{c}\text { Trait } \\
6 \mathrm{MW}, \mathrm{kg}\end{array}$} \\
\hline & & $\mathrm{N}$ & Mean $\pm S D$ & $\mathrm{~N}$ & Mean \pm SD & $\mathrm{N}$ & Mean $\pm S D$ & $\mathrm{~N}$ & Mean $\pm S D$ & $\mathrm{~N}$ & Mean $\pm S D$ \\
\hline & $\mathrm{F}=0$ & 1603 & $4.36 \pm 0.70^{\mathrm{a}}$ & 1641 & $22.09 \pm 4.44^{b}$ & 1235 & $32.28 \pm 5.24^{b}$ & 902 & $36.41 \pm 5.26^{a}$ & 462 & $39.84 \pm 7.41^{\mathrm{a}}$ \\
\hline \multirow[t]{3}{*}{ Male } & $0<\mathrm{F} \leq 0.10$ & 479 & $4.46 \pm 0.72^{\mathrm{a}}$ & 459 & $22.73 \pm 4.78^{b}$ & 296 & $31.22 \pm 5.06^{b}$ & 161 & $35.05 \pm 4.85^{\mathrm{a}}$ & 114 & $37.03 \pm 5.01^{\mathrm{a}}$ \\
\hline & $F>0.10$ & 34 & $4.54 \pm 0.94^{a}$ & 31 & $24.83 \pm 3.96^{\mathrm{a}}$ & 28 & $34.47 \pm 5.35^{\mathrm{a}}$ & 20 & $36.32 \pm 5.15^{a}$ & 7 & $39.62 \pm 4.85^{\mathrm{a}}$ \\
\hline & $\mathrm{F}=0$ & 1600 & $4.73 \pm 0.77^{a}$ & 1627 & $24.30 \pm 5.31^{\mathrm{a}}$ & 1271 & $36.78 \pm 6.50^{\mathrm{a}}$ & 953 & $40.32 \pm 5.98^{b}$ & 622 & $39.47 \pm 7.03^{\mathrm{ab}}$ \\
\hline \multirow[t]{2}{*}{ Fem. } & $0<\mathrm{F} \leq 0.10$ & 427 & $4.73 \pm 0.81^{\mathrm{a}}$ & 418 & $24.11 \pm 5.70^{\mathrm{a}}$ & 286 & $34.31 \pm 6.48^{b}$ & 187 & $38.27 \pm 5.85^{b}$ & 124 & $38.05 \pm 6.22^{b}$ \\
\hline & $\mathrm{F}>0.10$ & 32 & $4.41 \pm 0.89^{b}$ & 30 & $24.76 \pm 6.22^{\mathrm{a}}$ & 22 & $35.92 \pm 8.51^{\mathrm{ab}}$ & 20 & $43.36 \pm 4.96^{\mathrm{a}}$ & 13 & $41.72 \pm 7.94^{\mathrm{a}}$ \\
\hline
\end{tabular}

${ }^{a, b}$ Means within a column and for each lamb sex that do not have a common superscript are significantly different $(P<0.05)$. BW: birth weight, 3MW: 3-month weight, 6MW: 6-month weight, 9MW: 9-month weight, YW: yearling weight

Table 4

Regression coefficients ( \pm SE) of body weight traits on inbreeding of lambs for a change of $1 \%$ in inbreeding

\begin{tabular}{lcccrc}
\hline Item & BW & 3MW & \multicolumn{1}{c}{ Traits } \\
& \multicolumn{1}{c}{$6 \mathrm{MW}$} & $9 \mathrm{MW}$ & $\mathrm{YW}$ \\
\hline Single & $-0.009 \pm 0.006$ & $0.007 \pm 0.047$ & $-0.029 \pm 0.068$ & $0.003 \pm 0.065$ & $-0.183 \pm 0.105^{* * *}$ \\
Twin & $-0.012 \pm 0.006^{* * *}$ & $0.129 \pm 0.057^{* *}$ & $-0.128 \pm 0.078$ & $-0.166 \pm 0.105$ & $-0.092 \pm 0.191$ \\
Male & $0.009 \pm 0.007$ & $0.126 \pm 0.048^{* *}$ & $0.081 \pm 0.062$ & $-0.071 \pm 0.071$ & $-0.357 \pm 0.155^{*}$ \\
Female & $-0.025 \pm 0.008^{* *}$ & $-0.020 \pm 0.058$ & $-0.234 \pm 0.079^{* *}$ & $-0.025 \pm 0.078$ & $-0.030 \pm 0.116$ \\
All & $-0.009 \pm 0.005^{* * *}$ & $0.057 \pm 0.040$ & $-0.079 \pm 0.056$ & $-0.045 \pm 0.059$ & $-0.159 \pm 0.095^{* * *}$ \\
\hline
\end{tabular}

${ }^{*}$ significant at $P<0.05,{ }^{* *}$ significant at $P<0.01,{ }^{* * *}$ trend for significance $(0.05<P<0.10)$. BW: birth weight, $3 \mathrm{MW}$ : 3-month weight, 6MW: 6-month weight, 9MW: 9-month weight, YW: yearling weight

Table 4 shows the regression coefficients of body weights on inbreeding of lambs for a change of $1 \%$ in inbreeding. There were trends for significance for the regression coefficients of BW and YW on inbreeding of all lambs. The regression coefficients of birth and yearling weights on lamb inbreeding were estimated to be $-0.009 \pm 0.005$ and $-0.159 \pm 0.095(P<0.08)$, respectively, then birth and yearling weights decreased respectively by $0.009 \mathrm{~kg}$ and $0.159 \mathrm{~kg}$ due to $1 \%$ increase in inbreeding. The regression coefficient of $3 \mathrm{MW}$ on inbreeding of lambs for change of $1 \%$ in inbreeding was positive and non significant, but the coefficients of $6 \mathrm{MW}$ and 9MW were negative and non significant. Considering the birth type, the regression coefficient of $3 \mathrm{MW}$ on inbreeding of twin-born lambs was significantly positive $(0.129 \pm 0.057$, $P<0.01)$. Therefore, $3 \mathrm{MW}$ of twins increased $0.129 \mathrm{~kg}$ due to $1 \%$ increase in inbreeding. There were trends for significance for the regression coefficients of $Y W$ in single-born lambs and BW in twin-born lambs and their corresponding values were $-0.183 \pm 0.105$ and $-0.012 \pm 0.006$, respectively $(P<0.10)$. Also, considering the sex of lambs, the $3 \mathrm{MW}$ and $\mathrm{YW}$ of male lambs 
increased and decreased respectively by $0.126 \mathrm{~kg}(P<0.01)$ and $0.357 \mathrm{~kg}(P<0.05)$ due to $1 \%$ increase in inbreeding. On the other hand, the BW and $6 \mathrm{MW}$ of female lambs decreased respectively by $0.025 \mathrm{~kg}(P<0.01)$ and $0.234 \mathrm{~kg}(P<0.01)$ due to $1 \%$ increase in inbreeding.

\section{Discussion}

The inbreeding level estimates are strongly determined by the two main factors: depth and completeness of pedigree and selection intensity. Selection intensity is often increased by the reproductive technologies being focused on a few superior animals (especially sires) and the application of advanced methods of genetic evaluation. A high inbreeding level is observed for populations rebuilt from small number of founders, but on the other hand in this case the accuracy is strongly determined by the incompleteness of pedigrees (Barczak et al. 2009). Consistent with the result of this study, Pedrosa et al. (2010) reported the average inbreeding was $2.33 \%$ in Santa Inês sheep in Brazil. But, Van Wyk et al. (2009) and Selvaggi et al. (2010) reported higher inbreeding rates in Elsenburg Dormer sheep (16\%) and Leccese sheep (8.1\%), respectively. The rapid increase in the rate of inbreeding in 1994 and 1998 could be resulted from the decrease in the number of sires. Also, some animals of the studied population had presented high levels of inbreeding, reflecting the intensive use of few sires. Similar to the current results, Barczak et al. (2009) reported positive trend for inbreeding over the years.

There are several methodological and biological factors which determine the estimated inbreeding impact on performance traits. It is well known that both negative effects and positive ones exist. Hence, in a given population, »bad« and "good« inbreeding effects are mixed (Barczak et al. 2009). Similar to the current results, Van Wyk et al. (1993) who observed a reduction of $0.008 \mathrm{~kg}$ in BW for a $1 \%$ increase of inbreeding in Dormer sheep, Ercanbrack and Knight (1991) who found a mean value of $-0.010 \mathrm{~kg}$, Khan et al. (1995) and Mirza et al. (1999) who reported a regression coefficient of -0.008 and -0.007 respectively. Also, similar to the present study, Barczak et al. (2009) reported for sheep of eight lines and breeds an average estimate of $-0.0095 \mathrm{~kg}$. MacKinnon (2003) obtained inbreeding depression results of $-0.012 \mathrm{~kg}$ for crossed sheep and Van Wyk et al. (2009), $-0.006 \mathrm{~kg}$ for the Elsenburg Dormer sheep breed. Causes of variation in inbreeding effects could be due to differences among breeds in alleles segregating, amount of genetic variation in the base population, location, management, and diversity of the founders in the flocks tested (MacKinnon 2003).

Similar to the current results, Lamberson \& Thomas (1984) reported no significant reduction of $3 \mathrm{MW}$ due to inbreeding in different breeds of sheep. The $3 \mathrm{MW}$ of twins and or male lambs was increased due to $1 \%$ increase in lamb inbreeding rate and inconsistent with the current result, Van Wyk et al. (2009) and Selvaggi et al. (2010) reported significant reduction in $3 \mathrm{MW}$ of lambs due to $1 \%$ increase in inbreeding. Lamb sex was a significant effect in the current analysis of inbreeding, but it should be noted that negligible differences between males and females was observed in the study of Barczak et al. (2007). Barczak et al. (2009) reported positive inbreeding effects on fourth week weight in a multi-breed sheep population. Also, the $6 \mathrm{MW}$ of female lambs was reduced $0.234 \mathrm{~kg}$ per $1 \%$ increase in inbreeding and similar to this result Pedrosa et al. (2010) reported a decrease of $0.204 \mathrm{~kg}$ in weight at 180 days due to $1 \%$ increase in inbreeding. To my knowledge, there was no 
published report regarding to the effect of inbreeding on $\mathrm{YW}$, but the results of this study indicated a significant reduction in YW of male lambs $(0.357 \mathrm{~kg})$ and a trend for significance for the effect of inbreeding on the YW of all lambs. The explanation for the strong inbreeding depression observed for YW in this study was the lower heritability of this trait compared to other weight traits of Moghani sheep (Ghavi Hossein-Zadeh \& Ardalan 2010), since traits of low heritability tend to show less additive genetic variation and more dominance deviation than more heritable traits (Lamberson \& Thomas 1984).

In conclusion, average inbreeding rate was $2.93 \%$ in Iranian Moghani sheep and an increasing trend for inbreeding was observed over the years. Both positive and negative inbreeding effects were found in the current study. From the results of this study it can be seen that there was a trend for the negative effects of inbreeding on the BW and YW of all lambs but the regression coefficients of other body weight traits on inbreeding of all lambs for a change of $1 \%$ in inbreeding were not significant. The results of this study indicated a significant reduction in YW of male lambs, but the $3 \mathrm{MW}$ of twins and or male lambs was increased due to $1 \%$ increase in lamb inbreeding rate. Although inbreeding depression was not generally a possible cause of the reduction in the growth performance of Iranian Moghani sheep until now, but the utilization of designed mating system, at the current flock, could be a suitable approach to maintain the level of inbreeding under control.

\section{References}

Analla M, Montilla JM, Serradilla JM (1998) Analyses of lamb weight and ewe litter size in various lines of Spanish Merino sheep. Small Rumin Res 29, 255-259

Barczak E, Wolc A, Szwaczkowski T, Wójtowski J (2007) Inbreeding and inbreeding depression on productive traits in sheep. In: DGfZ (ed.) [Perspectives of the sheep and goat production in Central Europe international scientific symposium]. DGfZ-Schriftenreihe 47, 71

Barczak E, Wolc A, Wójtowski J, Ślósarz P, Szwaczkowski T (2009) Inbreeding and inbreeding depression on body weight in sheep. J Anim Feed Sci 18, 42-50

Dario C, Bufano G (2003) [Effect of inbreeding on milk production in Altamurana sheep breed].

Ercanbrack SK, Knight AD (1991) Effects of inbreeding on reproduction and wool production of Rambouillet, Targhee, and Columbia ewes. J Anim Sci 69, 4734-4744

Ghavi Hossein-Zadeh N, Ardalan M (2010) Comparison of different models for the estimation of genetic parameters of body weight traits in Moghani sheep. Agric Food Sci 19, 207-213

Khan MS, Ahmad MD, Ahmad Z, Jadoon JK (1995) Effect of inbreeding on performance traits of Rambouillet sheep. J Anim Plant Sci 5, 299-304

Khan MS, Ali A, Hyder AU, Chatta Al (2007) Effect of inbreeding on growth and reproduction traits of Beetal goats, Arch Tierz 50, 197-203

Lamberson WR, Thomas DL (1984) Effects of inbreeding in sheep: a review. Anim Breed Abstr 52, 287-297

Lush JL (1945) Animal Breeding Plans. lowa State College Press, Ames, lowa, USA

MacKinnon KM (2003) Analysis of Inbreeding in a Closed Population of Crossbred Sheep. MSc Thesis, Virginia Polytechnic Institute and State University Blacksburg, Virginia, USA

Mirza RH, Abdullah M, Ali I, Hussain R (1999) Effect of inbreeding on body weight in Lohi sheep. J Anim Plant Sci 9 (1), 25-27

Negussie E, Abegaz S, Rege JOE (2002) Genetic trend and effects of inbreeding on growth performance of tropical fat-tailed sheep. Proc. 7th World Congress on Genetics Applied to Livestock Production, Montpellier, France, August, 2002. Session 25, 1-4 
Pedrosa VB, Santana Jr ML, Oliveira PS, Eler JP, Ferraz JBS (2010) Population structure and inbreeding effects on growth traits of Santa Inês sheep in Brazil. Small Rumin Res 93, 135-139

Sargolzaei M, Iwaisaki H, Colleau JJ (2006) Proc. 8th World Congress on Genetics Applied to Livestock Production, Belo Horizonte, Minas Gerais, Brazil, 13-18 August, 27-28

Selvaggi M, Dario C, Peretti V, Ciotola F, Carnicella D, Dario M (2010) Inbreeding depression in Leccese sheep. Small Rumin Res 89, 42-46

Shodja J, Nosrati M, Alijani S, Pirani N (2006) [Estimation of genetic and phenotypic parameters for body weight at different ages and yearly wool production in Moghani sheep]. Knowledge Agric 57, $153-162$ [in Persian]

van Wyk JB, Fair MD, Cloete SWP (2009) Case study: the effect of inbreeding on the production and reproduction traits in the Elsenburg Dormer sheep stud. Livest Sci 120, 218-224

van Wyk JB, Erasmus GJ, Konstantinov KV (1993) Inbreeding in the Elsenburg Dormer sheep stud. S Afr J Anim Sci 23, 77-80

Received 5 May 2011, accepted 10 January 2012.

Corresponding author:

Navid Ghavi Hossein-Zadeh

email: nhosseinzadeh@guilan.ac.ir or navid.hosseinzadeh@gmail.com

Department of Animal Science, Faculty of Agriculture, University of Guilan, P. O. Box: 41635-1314, Rasht, Iran 